\title{
Legal Aid in the Criminal Matters in Jordan
}

\author{
Muath Al-Zoubi \\ School of Law, The University of Jordan, PO box 13368 Amman 11942 Jordan
}

\begin{abstract}
The idea of legal aid has emerged from fundamental rights associated with litigation such as the right to access justice, the right to fair trial, the right to defence, and the right to equality. The notion of regulating legal aid is relatively new in Jordan despite its significance. This paper examines the regulation of legal aid in Jordan through describing and analysing the existing literature concerning legal aid and defining the law as well as examining how it applies to legal aid. It is noteworthy that there has been a rise in the demand for legal aid and Jordan has taken certain steps towards establishing a holistic approach to provide the necessary legal aid. This paper concludes that legal aid should be treated as a fundamental right rather than a grant given by the government to people.
\end{abstract}

Keywords: Legal aid, Access to justice, Jordanian legislation

DOI: $10.7176 / \mathrm{JLPG} / 93-08$

Publication date: January $31^{\text {st }} 2020$

\section{Introduction}

The concept of legal aid can be dated back to the fourteenth century when the lawyers were responsible for investing a certain time to those who are unable to pay. ${ }^{1}$ Legal aid is regarded as an essential element in criminal justice system. ${ }^{2}$ Everyone should be able to access justice regardless of whether they can afford an attorney. However, several individuals suffer from lack of access to justice services because of their inability to pay wages to attorneys, thus violating their rights to access justice. This may affect the stability of a society by shaking its confidence in the judiciary and weakening compliance with the law. Further, there are cases where people who are unable to access justice services take justice into their own hands using force, violence, and seeking revenge. This leads to damaging the security of the community.

The Jordanian Department of Statistics has estimated that, every year, approximately 47,000 people in Jordan involved with the justice system cannot afford an attorney. Moreover, $96 \%$ people who violate the law are people with low income, and $83 \%$ defendants remain unrepresented during the investigation as well as pretrial stages. This percentage drops to $68 \%$ in the court stage. ${ }^{3}$

This paper will focus on the legal aid in Jordan and will particularly take into consideration legal aid concerning criminal matters. This paper describes and analyses the existing literature including primary and secondary sources regarding legal aid by defining law and how it applies to legal aid. In doing so, this paper will establish certain results and recommendations that can be used to better understand legal aid. Moreover, the absence of a legally comprehensive addressing of the legal aid in Jordan will also be presented, along with exploring the practical gaps in the efforts made to address the legal aid problem.

This paper focuses on the legal aid in criminal matters in Jordan by highlighting the following issues: the conceptual framework of legal aid, regulation of legal aid in Jordan, reasons for lawyers to provide legal aid, the rights and obligations of the attorney assigned to provide legal aid, and the efforts made by the government in Jordan regarding legal aid.

\section{Identifying Legal Aid:}

This section addresses the following issues:

\subsection{The Conceptual Framework:}

Legal aid has been defined as per the Jordanian Regulation of Legal Aid as the legal representation before the public prosecution departments, statutory courts, and the Grand Criminal Court in accordance with the provisions of the legislation in force. ${ }^{4}$ Thus, legal aid is limited to one aspect which is the legal representation. Legal aid is also limited to specific judicial bodies including the public prosecution departments, statutory courts, and the Grand Criminal Court and does not include legal representation before other judicial bodies such as religious courts and special courts.

The Instructions for the Organisation of Legal Aid Provided by the Ministry of Justice has also defined

\footnotetext{
${ }^{1}$ Howard Dana, 'Legal Aid and Legal Services: An Overview' (2015) 67 Me L Rev 276, 276.

${ }^{2}$ United Nations Office on Drugs and Crime (UNODC), 'United Nations Principles and Guidelines on Access to Legal Aid in Criminal Justice Systems' (2013), Para. 14

${ }^{3}$ This has been pointed out by Jordan's Justice Center for Legal Aid in a summary of the justice system's reality. See Center for Legal Aid, 'It All Begins With Justice' (2018) < http://www.jcla-org.com/en/publication/it-all-begins-justice> accessed 26 December 2019, 3-4.

${ }^{4}$ The Jordanian Regulation of Legal Aid (No 119 of 2018) page 6675 of the Official Gazette (No 5541) dated 1 November 2018 , Art. 2.
} 
legal aid as providing legal advice and representation in cases in authorised by law before the courts as well as public prosecution. ${ }^{1}$

These two definitions are the only legal definitions for the term 'legal aid' under the Jordanian legislation. Both definitions agree that legal aid involves legal representation and that legal aid could take place before public prosecution. However, the definition stated in the Instructions for the Organisation of Legal Aid Provided by the Ministry of Justice has a wider scope because it includes legal advice along with legal representation. It also uses the expression 'the courts' without specifying which courts, thereby also including other courts stated in the Jordanian Constitution which are civil courts, religious courts, and special courts. ${ }^{2}$ Therefore, this definition can be considered to be more extensive compared to that provided by the Jordanian Regulation of Legal Aid which uses the expression 'the statutory courts', thus limiting these courts to only one category of courts.

The right to legal aid has been addressed under the Basic Principles on the Role of Lawyers. In this regard, it states that:

Any such persons who do not have a lawyer shall, in all cases in which the interests of justice so require,

be entitled to have a lawyer of experience and competence commensurate with the nature of the offence assigned to them in order to provide effective legal assistance, without payment by them if they lack sufficient means to pay for such services. ${ }^{3}$

According to this principle, any person who cannot afford a lawyer financially is entitled to have legal assistance free of charge and regardless of the case if the justice interests required.

In addition, the Universal Declaration of Human Rights implicitly addresses the issue of legal aid. Article seven states that '[a]ll are equal before the law and are entitled without any discrimination to equal protection of the law'. ${ }^{4}$ Article eight states that 'everyone has the right to an effective remedy by the competent national tribunals for acts violating the fundamental rights granted him by the constitution or by law'. ${ }^{5}$ Article ten states that '[e]veryone is entitled in full equality to a fair and public hearing by an independent and impartial tribunal, in the determination of his rights and obligations and of any criminal charge against him' ${ }^{6}$ Article eleven states that '[e]veryone charged with a penal offence has the right to be presumed innocent until proved guilty according to law in a public trial at which he has had all the guarantees necessary for his defence'. ${ }^{7}$ These articles implicitly recognise the importance of legal aid by assuring that people are equal in their legal rights, including the right to legal aid.

\subsection{Regulating the Legal Aid in Jordan}

In Jordan, there is no comprehensive legal framework that addresses legal aid. There is also a lack of cooperation among bodies related to legal aid. However, it can be argued that there are certain articles in the Jordanian Constitution that addresses this subject implicitly: Article Six states that 'Jordanians shall be equal before the law. There shall be no discrimination between them as regards to their rights and duties on grounds of race, language or religion'. 8 The same Article states also that 'the Government shall ensure work and education within the limits of its possibilities, and it shall ensure a state of tranquillity and equal opportunities to all Jordanians'. ${ }^{9}$ Thus, this Article affirms the equality among Jordanians.

Under the fundamental right of access to justice, Article 101 states that 'the courts shall be open to all and shall be free from any interference in their affairs'. ${ }^{10}$ This Article recognises the fundamental right of access to justice. Nonetheless, this could be challenged on the basis that although the Jordanian Constitution, which is ranked the highest in the legislative level, recognises the right of access to justice in Article $101,{ }^{11}$ most of the legal matters concerning legal counsel or representation's right are not fully guaranteed by Jordanian laws. In particular, the government does not ensure legal aid by paying attorneys to represent those who cannot afford them, except in certain criminal cases with certain punishments. For example, as per Article 208 of the Jordanian Code of Criminal Procedures, whoever is criminally accused with a crime that may result in the accused being sentenced to the death penalty, life imprisonment, life detention, or temporary imprisonment of ten years or more

\footnotetext{
${ }^{1}$ Instructions for the Organisation of Legal Aid Provided by the Ministry of Justice (No 1 of 2016) page 1533 of the Official Gazette (No 5387) dated 16 March 2016.

${ }^{2}$ The Jordanian Constitution (1952) page 3 of the Official Gazette (No 1093) dated 8 January 1952, Art. 99.

${ }^{3}$ United Nations, Basic Principles on the Role of Lawyers, adopted by the Eighth United Nations Congress on the Prevention of Crime and the Treatment of Offenders, Havana, Cuba, 27 August to 7 September 1990, Para.6.

${ }^{4}$ Universal Declaration of Human Rights (adopted by the United Nations General Assembly on 10 December 1948), G.A. res. 217A (III),

U.N. Doc A/810 at 71 (1948) Art. 7.

5 ibid, Art. 8.

${ }^{6}$ ibid, Art. 10.

7 ibid, Art. 11(1).

${ }^{8}$ The Jordanian Constitution (1952) Art. 6(i).

9 ibid, Art. 6(iii)

${ }^{10}$ ibid, Art. 101(i).

${ }^{11}$ Justice Center for Legal Aid, <http://www.jcla-org.com/en/legal-aid-jordan> accessed 26 December 2019.
} 
is entitled by the state to be represented by legal counsel. ${ }^{1}$

Moreover, under Article 63 bis of the Jordanian Code of Criminal Procedures, for felonies with a minimum sentence of ten years, an attorney must be present with the defendant during every interrogation, and if the defendant is unable to afford an attorney, the public prosecutor will take the necessary measures to appoint an attorney for the defendant in accordance with the provisions of the legislation in force. ${ }^{2}$

The Jordanian Bar Association has addressed the issue of providing legal aid as one of the Bar's objectives is providing professional work to its members and ensuring cooperation in the practice of the legal profession as well as providing judicial aid to citizens unable to afford it. ${ }^{3}$ Article 78 of the same Law, which establishes the necessary regulations to implement this Law, clearly stipulates that the regulation of legal aid is one of the regulations that must be established. ${ }^{4}$

Additionally, under the Jordanian Bar Association Law, the Chairman of the Bar may assign an attorney on a pro bono basis to defend an individual who can prove their financial inability to hire an attorney to the Chairman. ${ }^{5}$ However, this pro bono assignment fails to consider specific guidelines concerning who is entitled to legal aid. Moreover, the decision of assigning an attorney on a pro bono basis is the sole responsibility of the Chairman of the Bar. ${ }^{6}$

The Jordanian Juvenile Law also addresses legal aid by clearly stipulating that the court must appoint an attorney for the juvenile in criminal cases if the juvenile does not have an attorney or is not able to hire one. The attorney fees will be paid from the state treasury in accordance with the Code of Criminal Procedures. ${ }^{7}$ Although this Law recognises the right to legal aid for juveniles, it limits this right to criminal cases.

\subsection{Why Lawyers Provide Legal Aid}

There are several reasons behind the significance of legal aid. First, legal aid ensures that an individual's right to be legally represented is not lost because of their inability to pay for such legal representation. Second, legal aid strengthens the connection between the person requiring legal aid and the government, society, and the legal system by building trust in law and the criminal justice system. Third, legal aid reduces the possibility of individuals forcibly taking justice into their hands because of being refused their rights under the law, leading to the individual turning from a right holder into a criminal. Fourth, it provides a way to access justice and improve the efficiency of litigation.

Further, it has been argued that legal aid is not provided for monetary gains and that its rewards can be found elsewhere. Legal aid lawyers may find satisfaction in finding solutions for extremely difficult problems that poor people face. ${ }^{8}$ Legal representation and advice are often considered essential for maintaining a fair hearing. ${ }^{9}$ It has also been observed that almost all legal aid programmes are led by lawyers who are completely devoted to providing legal help to the poor. ${ }^{10}$

\subsection{The Rights and Obligations of the Attorney who is Assigned to Provide Legal Aid:}

Any attorney who is assigned to provide legal aid in accordance with Article 208(1) and Article 208(2) for felonies that are punishable with the death penalty, life imprisonment, life detention, or temporary imprisonment for ten years or more is entitled to receive a payment from the Legal Aid Fund of 30 Jordanian Dinar for each session attended, provided the wage for all sessions does not exceed 1300 Jordanian Dinar. ${ }^{11}$ However, if the attorney is assigned to provide legal aid in accordance with Article 208(3) and Article 208(4) for felonies punishable with temporary imprisonment of less than ten years, or if the attorney is assigned to aid competent official authorities or any of the concerned institutions or any citizen or resident in Jordan who unable to appoint an attorney, they will receive a payment from the Legal Aid Fund of 25 Jordanian Dinar for each session attended, provided the wage for all sessions does not exceed 1000 Jordanian Dinar. ${ }^{12}$ Although Article 208 sets the maximum limit of the attorney's wages, it does not set the minimum wage for the attorney. However, this could be challenge on the basis that in certain cases such payment might not commensurate with the effort made by the attorney especially that when the case is complicated and requires great efforts representing the applicant

\footnotetext{
${ }^{1}$ The Jordanian Code of Criminal Procedures, as amended (No 9 of 1961) page 311 of the Official Gazette (No 1539) dated 16 March 1961, Art. 208.

2 ibid, Art. 63 bis

${ }^{3}$ The Jordanian Bar Association Law, as amended (No 11 of 1972) page 666 of the Official Gazette (No 2357) dated 6 April 1972, Art. 5(5).

4 ibid, Art. 78.

5 ibid, Art. 100(7)

${ }^{6}$ Latham \& Watkins LLP (2010), Pro Bono Practices and Opportunities in Jordan, 3.

${ }^{7}$ The Jordanian Juvenile Law (No 32 of 2014) page 6371 of the Official Gazette (No 5310) dated 2 November 2014, Art. 21(a).

${ }^{8}$ Geoffrey Cowper, 'Legal Aid: a Catalyst for Change' (2008) 66 Advocate (Vancouver) 521, 523.

${ }^{9}$ Charles Davison, 'The Right to Fairness: Legal Aid' (2000) 24 LawNow 22, 24.

${ }^{10}$ Steven Eppler-Epstein, 'Passion, Caution, and Evolution: The Legal Aid Movement and Empirical Studies of Legal Assistance' (20122013) 126 Harv L Rev F 102, 103.

${ }^{11}$ The Jordanian Regulation of Legal Aid (No 119 of 2018) Art. 8(A).

12 ibid, Art. 8(B)
} 
for the legal aid.

It is required in order to pay for the attorney for his/her works issuing a final judicial verdict in the lawsuit that he/she is working on. ${ }^{1}$ The right of payment is forfeited if the attorney fails to attend two or more sessions without providing an excuse that is acceptable by the court. ${ }^{2}$ This is what is required for the attorney to deserve the payment under this aforementioned Article without considering the quality of their provided services. This may also be reflected in the legal aid that they offer.

The Minister of Justice shall inform the Jordanian Bar Association of those attorneys who have failed to provide the legal aid assigned to them so that the Bar Association can take the necessary disciplinary measures against them as per the Jordanian Bar Association Law. ${ }^{3}$ This failure to provide legal aid will lead to these attorneys not being appointed again for legal aid. ${ }^{4}$

\section{The Jordanian Efforts Regarding the Legal Aid:}

This section examines certain efforts made by the government in Jordan concerning the issue of legal aid.

\subsection{Being a State Party to a Number of Conventions Concerning Legal Aid:}

Jordan has become a state party to multiple conventions that deal with legal aid directly or indirectly. This clearly indicates that 'the political-will' in Jordan complies with international standards regarding legal aid. Nevertheless, becoming a state party to such conventions are not necessarily an indication of the fundamental obligations concerning compliance. Moreover, for certain conventions to be implemented, legal processes must be adopted internally to incorporate these conventions under the Jordanian legal system and so that these conventions have a national impact. However, there is another category of conventions that is subjected to the rule of self-execution. Under this rule, there is no need to incorporate certain international laws for them to be effective internally. ${ }^{5}$

It should be noted that the Jordanian Constitution does not address the issue of precedence between conventions and Jordanian legislation. However, precedence has been given to the application of conventions over national legislation by the Jordanian courts. ${ }^{6}$ This may be because these courts do not want any conflict with conventions as it may be considered an embarrassment for any government. ${ }^{7}$ In fact, states are obligated to comply with international law, and failing this obligation can lead to the state being held responsible for noncompliance. ${ }^{8}$ The Vienna Convention on the Law of Treaties has addressed this matter by stipulating in Article 27 that 'a party may not invoke the provisions of its internal law as justification for its failure to perform a treaty'. 9

International law also does not clarify the relationship between national law and international law in terms of enforcing or implementing international law at a national level. Consequently, national constitutions address this relationship by determining the integration of international law within the state legal system. ${ }^{10}$ There are two theories examining this relationship: the monist theory and the dualist theory. According to the monist theory, it is not necessary to transform international obligations into national law. ${ }^{11}$ This theory also considers at the law as entirely unitary ${ }^{12}$ as well as supports the notion of the supremacy of international law over national legal norms in case of conflict. ${ }^{13}$ In contrast, as per the dualist theory, it is necessary to transform international rules into national law. ${ }^{14}$ This theory also argues that national and international law exist separately, ${ }^{15}$ and thus, in case of conflict, national courts will apply the national law. ${ }^{16}$

In Jordan, the legal mechanisms for integrating conventions into the legal system have been divided into two mechanisms. The first mechanism is the 'self-executing' mechanism. ${ }^{17}$ As per this mechanism, the Jordanian

\footnotetext{
${ }^{1}$ ibid, Art. 8(C).

2 ibid, Art. 8(D).

3 ibid, Art. 9(C).

${ }^{4}$ ibid, Art. 9(D).

${ }^{5}$ Ian Brownlie, Principles of Public International Law (7th edn, Oxford University Press 2008) 48

${ }^{6}$ Mohamed Olwan, 'Trafficking in Persons in Jordan' (2011) CRIMES AS 2011/42, Robert Schuman Centre for Advanced Studies, San Domenico di Fiesole (FI): European University Institute 1, 6.

${ }^{7}$ Malcolm Evans, International Law (4th edn, Oxford University Press 2014) 432-433.

${ }^{8}$ Malcolm N. Shaw, International Law (6th edn, Cambridge University Press 2008) 131

${ }^{9}$ Vienna Convention on the Law of Treaties (adopted 23 May 1969, entered into force 27 January 1980) 1155 UNTS 331 , Art. 27.

${ }^{10}$ Malcolm Evans, International Law (4th edn, Oxford University Press 2014) 412, 417.

11 ibid, 418 .

${ }^{12}$ Malcolm N. Shaw, International Law (6th edn, Cambridge University Press 2008) 131.

${ }^{13}$ Malcolm Evans, International Law (4th edn, Oxford University Press 2014) 418; Ilias Bantekas and Efthymios Papastavridis, International Law Concentrate: Law Revision and Study Guide (Oxford University Press 2015) 49.

${ }^{14}$ Malcolm Evans, International Law (4th edn, Oxford University Press 2014) 418

${ }^{15}$ Malcolm N. Shaw, International Law (6th edn, Cambridge University Press 2008) 131; Ilias Bantekas and Efthymios Papastavridis, International Law Concentrate: Law Revision and Study Guide (Oxford University Press 2015) 49.

${ }^{16}$ Ian Brownlie, Principles of Public International Law (7th edn, Oxford University Press 2008) 32.

${ }^{17}$ Mohammed Al-Moosa, 'The Application of International Conventions for Human Rights in the Jordanian Judiciary: The reality and Ways
} 
Constitution does not establish a relationship between national and international law, ${ }^{1}$ but it stipulates that 'treaties and agreements which involve financial commitments to the Treasury or affect the public or private rights of Jordanians shall not be valid unless approved by the Parliament'. ${ }^{2}$ Accordingly, any convention that is not included in either of the previous two categories of having 'financial commitments to the Treasury' or impacting 'the public or private rights of Jordanians' may be subjected to automatic implementation after it being ratified and published in the Official Gazette. Notably, several conventions have been published in the Official Gazette that address legal aid directly or indirectly, thus suggesting that such conventions are considered part of its legal system. Consequently, the courts in Jordan will enforce them. ${ }^{3}$

The second mechanism is the referral mechanism according to which the recognised rights stated in conventions can be applied by the national judge. These rights are regarded as international rights. ${ }^{4}$

To return to an earlier point, Jordan is a state party to following conventions that deal with the legal aid directly or indirectly:

The Arab Charter on Human Rights implicitly addresses the issue of legal aid by stating that all persons are equal before the law and have the right to enjoy its protection without discrimination. ${ }^{5}$ It also states that all persons are equal before the courts. ${ }^{6}$ Additionally, the Arab Charter on Human Rights explicitly stipulates that every person has the right to a fair trial and that each state party guarantees that those without financial assistance are provided with legal aid to defend their rights. ${ }^{7}$ The Arab Charter on Human Rights was published on the Jordanian Official Gazette. ${ }^{8}$

Legal aid has been addressed explicitly under the International Covenant on Civil and Political Rights. In this regard, it has been stated that:

In the determination of any criminal charge against him, everyone shall be entitled to the following minimum guarantees, in full equality: ... (d) To be tried in his presence, and to defend himself in person or through legal assistance of his own choosing; to be informed, if he does not have legal assistance, of this right; and to have legal assistance assigned to him, in any case where the interests of justice so require, and without payment by him in any such case if he does not have sufficient means to pay for it. ${ }^{9}$

Jordan ratified the International Covenant on Civil and Political Rights on 28 May $1975^{10}$ and was published in the Jordanian Official Gazette. ${ }^{11}$ Therefore, its international obligations are bound for Jordan.

Under Article 55 of the Rome Statute of the International Criminal Court entitled 'rights of persons during an investigation', it has been stated that in paragraph two:

Where there are grounds to believe that a person has committed a crime within the jurisdiction of the Court and that person is about to be questioned either by the Prosecutor, or by national authorities pursuant to a request made under Part 9, that person shall also have the following rights of which he or she shall be informed prior to being questioned: ... (c) To have legal assistance of the person's choosing, or, if the person does not have legal assistance, to have legal assistance assigned to him or her, in any case where the interests of justice so require, and without payment by the person in any such case if the person does not have sufficient means to pay for it. ${ }^{12}$

Article 67 of the Rome Statute of the International Criminal Court entitled 'rights of the accused' also states in paragraph one that:

In the determination of any charge, the accused shall be entitled to a public hearing, having regard to the provisions of this Statute, to a fair hearing conducted impartially, and to the following minimum guarantees, in full equality: ... (d) Subject to article 63, paragraph 2, to be present at the trial, to conduct the defence in person or through legal assistance of the accused's choosing, to be informed, if the accused does not have legal assistance, of this right and to have legal assistance assigned by the Court in any case

Available’ Tamkeen for Legal Aid and Human Rights (Arabic edn) 43

${ }^{1}$ ibid, 36-37.

${ }^{2}$ The Jordanian Constitution (1952) Art. 33(2).

${ }^{3}$ Muddather Abu-Karaki, Raed Faqir and Majed Marashdah, 'Democracy \& Judicial Controlling in Jordan: A Constitutional Study' (2011)

4(2) Journal of Politics and Law 180, 186.

${ }^{4}$ Mohammed Al-Moosa, 'The Application of International Conventions for Human Rights in the Jordanian Judiciary: The reality and Ways Available' Tamkeen for Legal Aid and Human Rights (Arabic edn) 40-43.

${ }^{5}$ League of Arab States, Arab Charter on Human Rights, (adopted on 15 September 1994, published on the Jordanian Official Gazette (No 4675), dated 16 September 2004, page 4478) Art. 11.

${ }^{6}$ ibid, Art. 12.

7 ibid, Art. 13(1).

${ }^{8}$ The Jordanian Official Gazette (No 4675) dated 16 September 2004, page 4478.

${ }^{9}$ International Covenant on Civil and Political Rights (entered into force 23 March 1976) G.A. res. 2200A (XXI), 21 U.N. GAOR Supp. (No. 16) at 52, U.N. Doc. A/6316 (1966) 999 UNTS 171, Art. 14(3)(d).

10 United Nations Treaty Collection, <https://treaties.un.org/Pages/ViewDetails.aspx?src=TREATY\&mtdsg_no=IV$4 \&$ chapter $=4 \&$ clang $=$ en $>$ accessed 26 Dec 2019

${ }^{11}$ The Jordanian Official Gazette (No 4764) dated 15 June 2006, page 2227.

${ }^{12}$ Rome Statute of the International Criminal Court, (adopted by the United Nations Diplomatic Conference of Plenipotentiaries on the Establishment of an International Criminal Court on 17 July 1998, entered into force 1 July 2002) ISBN No. 92-9227-227-6, Art 55(2)(c). 
where the interests of justice so require, and without payment if the accused lacks sufficient means to pay for it. ${ }^{1}$

Articles 55(2)(c) and 67(1)(d) provide guidance on the implementation of legal aid in the investigation and trial stages under the Rome Statute of the International Criminal Court, which was ratified in Jordan on 11 April $2002^{2}$ and was published in the Jordanian Official Gazette. ${ }^{3}$

The Convention on the Rights of the Child addresses the right to legal aid implicitly, when it states that:

To this end, and having regard to the relevant provisions of international instruments, State Parties shall,

in particular, ensure that: ... (iii) To have the matter determined without delay by a competent,

independent and impartial authority or judicial body in a fair hearing according to law, in the presence of

legal or other appropriate assistance and, unless it is considered not to be in the best interests of the child,

in particular, taking account his or her age or situation, his or her parents of legal guardians. ${ }^{4}$

Moreover, on 24 May 1991, Jordan ratified the Convention on the Rights of the Child, ${ }^{5}$ and it was published in the Jordanian Official Gazette. ${ }^{6}$

The International Convention on the Elimination of All Forms of Racial Discrimination also implicitly ensures the right to legal aid by stating that ' $[\mathrm{t}] \mathrm{he}$ right to equal treatment before the tribunals and all other organs administering justice'. 7 Jordan accessed the International Convention on the Elimination of All Forms of Racial Discrimination on 30 May $1974,{ }^{8}$ and it was published in the Jordanian Official Gazette. ${ }^{9}$

Thus, it can be argued that legal aid has been addressed under international law from a human rights perspective. ${ }^{10}$ Almost all significant international human rights instruments have addressed the right to legal aid. Further, these instruments also lead to the defendant feeling entitled to a court appointed counsel without cost when deemed necessary as per judicial interests. ${ }^{11}$

\subsection{Enacting the Jordanian Regulation of Legal Aid (No 119 of 2018):}

This regulation is significant for three major reasons, as given below.

The first reason is that the regulation determines the eligibility for legal aid depending on the following criteria: ${ }^{12}$ First, the total monthly income of the applicant's family must not exceed 400 Jordanian Dinar. ${ }^{13}$ In this case, the following solution can be considered. If a member of a family is in conflict with their family and has no access to their family income, this member's income should be the only income to be considered for the eligibility of legal aid. ${ }^{14}$ Second, the applicant must not possess any immovable property except their residence, or the applicant must not possess any movable property except for the monthly income described in the previous criterion. ${ }^{15}$ However, in special and justified cases, the Minister of Justice may approve the provision of legal assistance to those with immovable property. ${ }^{16}$ Third, the type of the crime that the applicant is being tried for must be a felony. ${ }^{17}$ Fourth, the applicant must not have been convicted through judicial judgment with a felony or misdemeanour. ${ }^{18}$

The second reason is that the regulation establishes certain priorities for granting legal aid to applicants:

First, there are priorities that are based on the group of the applicants. Under this criterion, the priority is given to the following groups in the order listed: juvenile; the elderly, women, persons with disabilities, and any other category determined by the Minister of Justice. Second, there are priorities that are based on the duration of the penalty when the penalty is a felony. Under this criterion, felonies with longer punishment are prioritised. Third,

\footnotetext{
${ }^{1}$ ibid, Art 67(1)(d).

${ }^{2}$ For more information see: <http://www.ilo.org/dyn/normlex/en/f?p=1000:11200:0::NO:11200:P11200_COUNTRY_ID:103201> accessed 26 Dec 2019.

${ }^{3}$ The Jordanian Official Gazette (No 4539) dated 16 April 2002.

${ }^{4}$ Convention on the Rights of the Child (entered into force 2 September 1990) G.A. res. 44/25, annex, 44 U.N. GAOR Supp. (No. 49) at 167, U.N. Doc. A/44/49 (1989), Art. 40(2)(iii).

${ }^{5}$ United Nations Treaty Collection, <https://reaties.un.org/pages/ViewDetails.aspx?src=TREATY\&mtdsg_no=IV-11\&chapter=4\&lang=en > accessed 26 Dec 2019.

${ }^{6}$ The Jordanian Official Gazette (No 4787) dated 16 October 2006, page 3993.

${ }^{7}$ International Convention on the Elimination of All Forms of Racial Discrimination (adopted and opened for signature and ratification by General Assembly resolution 2106 (XX) of 21 December 1965, entered into force 4 January 1969) 660 UNTS 195, Art. 5(a).

8 United Nations Treaty Collection, <https://treaties.un.org/Pages/ViewDetails.aspx?src=TREATY\&mtdsg_no=IV2\&chapter=4\&clang=_en $>$ accessed 26 Dec 2019.

${ }^{9}$ The Jordanian Official Gazette (No 4764) dated 15 June 2006, page 2220.

${ }^{10}$ Raman Mittal and K.V. Sreemithum (eds), Legal Aid: Catalyst for Social Change (Raman Mittal 2012$) 4$.

${ }^{11}$ Hafida Lahiouel, 'Legal Aid in International Courts' (2000) 25 Int'l Legal Prac 109, 109.

${ }^{12}$ The Jordanian Regulation of Legal Aid (No 119 of 2018) Art. 3(A).

13 ibid, Art. 3(A)(1).

${ }^{14}$ United Nations Office on Drugs and Crime (UNODC), 'United Nations Principles and Guidelines on Access to Legal Aid in Criminal Justice Systems' (2013), Para. 41(f).

${ }^{15}$ The Jordanian Regulation of Legal Aid (No 119 of 2018) Art. 3(A)(2).

16 ibid, Art. 3(B)

17 ibid, Art. 3(A)(3).

18 ibid, Art. 3(A)(4).
} 
there are priorities that are based on the number of family members of the applicant. Under this criterion, applicants with larger families are prioritised. ${ }^{1}$

The third reason is that the regulation explains the procedures to submit an application of legal aid: ${ }^{2}$

Step one: The application of legal aid shall be submitted in accordance with the form approved by the Minister of Justice. Then, this application will be referred to the Directorate of Legal Aid in the Ministry of Justice within two working days from the date of its submission. Next, the Directorate must ensure that the application includes all the data and meets all the necessary conditions. The application must also be registered in the special register at the Directorate. After that, the application will be studied and verified by the Directorate by considering the applicability of the criteria and the conditions required in the application in accordance with the Jordanian Regulation of Legal Aid. Subsequently, within five working days from the date of receiving the application, the Directorate will recommend to the Minister of Justice whether the application should be accepted or rejected,

Step two: The Minister of Justice decides whether the application should be accepted or rejected within three working days from the date of the Directorate's recommendation,

Step three: If the legal aid application is accepted, the Minister of Justice may pay the expenses of the legal aid using the Legal Aid Fund established in the Ministry of Justice and assign an attorney from the list prepared for this purpose in coordination with the Jordanian Bar Association, or the Minister may request the Jordanian Bar Association to provide complete legal aid to the applicant in accordance with the legislation in force, or the Minister may assign an attorney to provide legal aid from the list of volunteer attorneys prepared by the Directorate,

Step four: The Directorate prepares a special file of legal aid applicants for the following reasons: following up the applicant's case, evaluating the legal aid provided to the applicant, reviewing the complaints received by the Directorate regarding the legal aid, and providing recommendations to the Minister of Justice to address the Jordanian Bar Association to take legal action,

Step five: If the legal aid application is rejected, the applicant may object to the rejection of his/her application within two working days from the date of them being notified of such rejection,

Step six: The Directorate shall notify the Prosecutor or the Court, as appropriate, of the Minister's decision if the application was referred to the Minister from either of them. ${ }^{3}$

\subsection{Establishing the Directorate of Legal Aid as well as the Department of Legal Aid in the Jordanian Ministry of Justice.}

This Directorate protects and respects human rights and public freedom by legitimising and ensuring their access and enjoyment. It also defends target groups' rights and provides legal aid to them as well as to the defence counsel of such target groups. ${ }^{4}$ This Department has four main aims: first is to provide legal aid to eligible groups; second is to enhance the legal aid system's efficiency for beneficiaries by managing and implementing legal aid works and procedures; third is conducting the Ministry's activities concerning capacity building and addressing legal aid issues, and fourth is building a legal aid database. ${ }^{5}$

For achieving these aims, the Department of Legal Aid can execute the following tasks and powers. ${ }^{6}$

1. Participating in developing executive plans concerning the Department of Legal Aid's programmes and projects and following-up and supervising their implementation as well as evaluating and proposing methods for developing work methodologies and procedures in accordance with the general policy adopted for this and assessing the performance of the divisions affiliated with the Department and liaison officers,

2. Developing criteria and bases for the eligibility for legal aid and the mechanisms that can help verify the applicability of such criteria while recommending the approval or rejection of granting legal aid,

3. Organising the process of accessing legal service providers for the categories that deserve legal aid as defined by the criteria approved by the Ministry,

4. Providing direct legal aid service based on the criteria approved by the Ministry,

5. Providing information regarding legal aid,

6. Supervising and evaluating the legal aid services provided to the eligible applicants from the relevant authorities,

7. Compiling research studies concerning legislation and their need to be adjusted as well as their alignment with international standards and preparing the necessary analytical studies,

8. Identifying the training needs of the staff in the Department of Legal Aid, Divisions affiliated with the

\footnotetext{
1 ibid, Art. 4

2 ibid, Art. 6.

3 ibid, Art. 6

${ }^{4}$ The Ministry of Justice , Directorate of Legal Assistance < http://www.moj.gov.jo/Pages/viewpage.aspx?pageID=1330 $>$ accessed 26 December 2019.

${ }^{5}$ Instructions for the Organisation of Legal Aid Provided by the Ministry of Justice (No 1 of 2016) Art.3.

${ }^{6}$ ibid, Art.4.
} 
Department, as well as of liaison officers and preparing and organising training programmes in cooperation with the concerned authorities,

9. Developing mechanisms of cooperation, communication, and coordination with civil society institutions and regional and international organisations working in the field of human rights and legal aid,

10. Preparing, studying, and analysing periodic reports regarding the work of the Department of Legal Aid and the divisions affiliated with the Department and submitting them to the Directorate,

11. Receiving the requests of legal aid submitted directly by liaison officers,

12. Supervising the legal aid divisions affiliated with the Department and liaison officers. ${ }^{1}$

Following are the procedures that the Department of Legal Aid follows when an application for legal aid is submitted: ${ }^{2}$

1. The applications for legal aid are submitted according to the form approved by the Minister of Justice. This form should particularly include the beneficiary's personal information such as their name, proof of identity, address, information on social and material status, the required legal service, type of case, criminal act, and signature of the applicant,

2. The Department of Legal Aid receives the legal aid applications submitted directly to the Department or sent to the Department by the divisions affiliated with the Department,

3. The Department of Legal Aid and the divisions affiliated with the Department audit the information and data included in the application as well as the accompanying documents,

4. The Department of Legal Aid verifies the eligibility criteria for legal aid as per the relevant laws in force and the criteria approved by the Ministry,

5. The Director of the Directorate of Human Rights and Family Affairs in the Ministry of Justice examines the application and then recommends whether legal aid should be provided by referring to free legal aid providers or if legal aid should be denied. The recommendation is then submitted to the Minister for approval,

6. If the recommendation stated that legal aid should be provided directly from the Ministry's financial allocations, the Director of the Directorate of Human Rights and Family Affairs attributes to the Director of Financial Affairs in the Ministry who then recommends to the Minister whether to accept or refuse the provision of legal aid considering the financial allocations' availability,

7. The applicant is then informed of the decision through any available means,

8. A special file is prepared for the legal aid applicant to follow up with the applicant's case and assess the legal service provided after a decision is made with the approval. ${ }^{3}$

\section{Results}

Having examined legal aid in Jordan in the previous sections, this paper has reached the following conclusions. The Ministry of Justice and the Jordanian Bar Association have not reached a unified criteria for regulating the entitlement of legal aid as each body uses its own criteria, with the Ministry of Justice relying on Article 3 of the Jordanian Regulation of Legal Aid and the Jordanian Bar Association relying on Article 100 of the Jordanian Bar Association Law.

The legal aid stipulated in the Jordanian Bar Association Law's Article 100 is subject to the Chairman of the Bar's discretion in terms of assigning an attorney for such legal aid. Thus, the Chairman is under no obligation to accept the request that is referred to him, in accordance with Article $6(\mathrm{C})(2)$ of the Jordanian Regulation of Legal Aid, by the Minister of Justice for providing complete legal aid to the applicant according to the legislation in force. Moreover, no procedural framework has been clearly outlined which regulates legal aid under the Jordanian Bar Association Law except Article 100 that addresses the assigning of an attorney to defend any person who can prove to the Chairman to be financially unable to afford one.

Legal aid is limited to the trial's duration. That is, the legal aid is limited to the when the crime in question is in the trial stage and is not provided in the preliminary stage or any stage of criminal procedures prior to the trial except during the interrogation stage before the public prosecutor where the crime in question refers to a felony with a minimum sentence of ten years. ${ }^{4}$

It should also be noted that legal aid centres are important for supporting the idea of legal aid and enhancing its application. However, these centres are considered unofficial channels for providing legal aid as legal aid is officially provided through the Ministry of Justice and the Jordanian Bar Association. Therefore, these legal aid centres have become controversial because although the existence of these centres is important for providing legal aid those in need and are considered supporters of the Jordanian Bar Association, they may be considered illegal centres as they rob the jurisdiction from the Jordanian Bar Association. It has thus been stated that the rules of the Bar Association have been used for deregistering legal aid providers for lawyers employed at legal

\footnotetext{
ibid.

2 ibid, Art.5.

3 ibid.

${ }^{4}$ The Jordanian Code of Criminal Procedures, Art. 63 bis
} 
aid offices. ${ }^{1}$

Despite Jordan having no special legislation that regulates the provision of legal aid by non-governmental organisations, ${ }^{2}$ these organisations do provide legal aid in Jordan. Thus, these organisations have faced certain obstacles. Particularly, such non-government service providers need donation or funding to provide legal aid to those in need. However, receiving such donation or funding from non-Jordanian individual necessitates certain conditions. First, the funding or donation's source must be legal and must not violate public order or morals. Second, the conditions determined by the donor or funder must not be in conflict with the provisions of the Jordanian Law of Societies and the society's bylaws. Third, the donations or funding must be spent or used for the purpose for which such donations or funding has been offered. ${ }^{3}$

It should also be noted that there is no effective monitoring system that properly oversees the quality of legal aid being provided.

\section{Conclusion}

Access to legal aid is significant for ensuring that the accused receives a fair trial. In fact, without proper legal representation, ordinary people may not have proper access to justice as the legal system has become quite complicated. ${ }^{4}$ The accessibility of legal aid is linked to the right to counsel. This right becomes meaningless for the accused persons if they have no access to legal aid. ${ }^{5}$ Thus, it is the duty of a state to guarantee that legal aid is provided at all stages of the criminal justice process to those who need it. $^{6}$ Hence, the absence of legal aid can lead to several litigants being unable to afford lawyer's services for representing their interests. ${ }^{7}$ Moreover, the pro bono practice has become considerably widespread throughout the legal profession. ${ }^{8}$ Legal representation and legal advice are considered the basis of any legal aid programme. ${ }^{9}$

There is also insufficient literature in Jordan regarding legal aid, and the data and information concerning legal aid is also mainly available in the Arabic language. Additionally, such data and information are derived from various bodies such as the Jordan Ministry of Justice, the Jordanian Bar Association, and legal aid centres. There is thus no specialised body that can be depended on as the primary source for such data and information. Furthermore, there are different legislations addressing legal aid in Jordan rather than having one specialised law that encompasses all aspects of legal aid. These legislations include the Code of Criminal Procedures, the Jordanian Bar Association Law, the Regulation of Legal Aid, and the Instructions for the Organisation of Legal Aid Provided by the Ministry of Justice. These also represent the limitations of this paper. Consequently, further studies are required that can address these limitations.

This paper examined legal aid concerning criminal matters in Jordan and has highlighted the conceptual framework of legal aid by focusing on the national definition of legal aid. It also evaluated how legal aid is regulated in Jordan and addressed the question of why lawyers provide legal aid. Subsequently, the rights and obligations of the attorney assigned to provide legal aid are also addressed. This paper has described the efforts made in Jordan regarding the legal aid and analysed them in detail. Finally, it has presented the conclusions and provided recommendations for improving the provision of legal aid in Jordan.

As this paper has concluded and summarised its findings, certain recommendations concerning legal aid in Jordan have emerged.

It is recommended that a special law regarding legal aid be established in terms of the Model Law on Legal Aid in Criminal Justice Systems that has been developed by the United Nations Office on Drugs and Crime (UNODC). ${ }^{10}$ Such a law should outline the purpose of legal aid and its definition as well as its scope of application. It must also provide guiding principles along with clarifying who are the beneficiaries and providers of legal aid. Furthermore, provisions regarding legal aid authorities should be added in this law, and particular attention must be given to the procedures of implementing legal aid.

It is recommended that the efforts being made in Jordan by the Ministry of Justice, the Jordanian Bar Association, and other bodies concerning legal aid be unified for verifying who has greater need of such legal aid among the applicants.

\footnotetext{
${ }^{1}$ WANA Institute, 'The Status of Legal Empowerment in Jordan: Evidence to support the post-2015 development agenda' (2015), 31.

${ }^{2}$ The Spanish Agency for International Development Cooperation (AECID), 'Access to Justice and Legal Empowerment in Jordan: Towards an Effective and Sustainable Legal Aid System' (2018), 4.

${ }^{3}$ The Jordanian Law of Societies (No 51 of 2008) page 4219 of the Official Gazette (No 4928) dated 16 September 2008, Art. 17(b).

${ }^{4}$ Graham Robertson and Elizabeth Robertson, 'Access to Justice and Legal Aid' (2011) 35 LawNow 21, 23.

${ }^{5}$ Asher Flynn and Others, 'Legal Aid and Access to Legal Representation: Redefining the Right to a Fair Trial' (2016) 40 Melb U L Rev 207, 210

${ }^{6}$ United Nations Office on Drugs and Crime (UNODC), 'United Nations Principles and Guidelines on Access to Legal Aid in Criminal Justice Systems' (2013), Para. 20

${ }^{7}$ Andrew Butler, 'Legal Aid before Human Rights Treaty Monitoring Bodies' (2000) 49 Int'l \& Comp LQ $360,372$.

${ }^{8}$ Austin Sarat (ed), Special Issue: Law Firms, Legal Culture and Legal Practice: Law Firms, Legal Culture, and Legal Practice (Emerald Group Publishing 2010) 146.

${ }^{9}$ Mayland McKimm, 'The Future of Legal Aid', (2010) 68 Advocate (Vancouver) 699, 700

${ }^{10}$ United Nations Office on Drugs and Crime (UNODC), Model Law on Legal Aid in Criminal Justice Systems with Commentaries (2017).
} 
It is also recommended that legal aid be provided to individuals throughout the process of criminal justice and not be limited to those subjected to certain punishments. This is important as it may prevent them from feeling victimised. Moreover, priority should be given to children, trafficked persons, refugees, people with disabilities, migrant workers, and victims of domestic violence.

It is advised that data be collected and studies and researches be conducted on legal aid as it can help establish a robust database that can help identify problems and find solutions related to legal aid. Moreover, a specialised body should be formed that can manage all issues regarding legal aid in Jordan.

It is also necessary that the bodies dealing with legal aid have good communication, cooperation, and share good practices. Mechanisms to monitor, oversee, and evaluate should also be established to ensure the quality of the legal aid being provided.

It is crucial that the government recognises the important role of non-state actors in providing legal aid, and thus regulate and monitor the work of legal aid centres. It is necessary to treat legal aid as a humanitarian issue that is not exclusive to a specific body and is instead a humanitarian duty of all capable bodies as long as they follow a humanitarian legal approach. Establishment of legal aid clinics should also be supported and encouraged.

\section{References}

Andrew Butler, 'Legal Aid before Human Rights Treaty Monitoring Bodies' (2000) 49 Int'1 \& Comp LQ 360.

Asher Flynn and Others, 'Legal Aid and Access to Legal Representation: Redefining the Right to a Fair Trial' (2016) 40 Melb U L Rev 207.

Austin Sarat (ed), Special Issue: Law Firms, Legal Culture and Legal Practice: Law Firms, Legal Culture, and Legal Practice (Emerald Group Publishing 2010).

Center for Legal Aid, 'It All Begins With Justice' (2018) < $\underline{\text { http://www.jcla-org.com/en/publication/it-all-begins- }}$ justice>.

Charles Davison, 'The Right to Fairness: Legal Aid' (2000) 24 LawNow 22.

Convention on the Rights of the Child (entered into force 2 September 1990) G.A. res. 44/25, annex, 44 U.N. GAOR Supp. (No. 49) at 167, U.N. Doc. A/44/49 (1989).

Geoffrey Cowper, 'Legal Aid: a Catalyst for Change' (2008) 66 Advocate (Vancouver) 521.

Graham Robertson and Elizabeth Robertson, 'Access to Justice and Legal Aid' (2011) 35 LawNow 21.

Hafida Lahiouel, 'Legal Aid in International Courts' (2000) 25 Int'l Legal Prac 109.

Howard Dana, 'Legal Aid and Legal Services: An Overview' (2015) 67 Me L Rev 276.

Ian Brownlie, Principles of Public International Law (7th edn, Oxford University Press 2008).

Ilias Bantekas and Efthymios Papastavridis, International Law Concentrate: Law Revision and Study Guide (Oxford University Press 2015).

Instructions for the Organisation of Legal Aid Provided by the Ministry of Justice (No 1 of 2016) page 1533 of the Official Gazette (No 5387) dated 16 March 2016.

International Convention on the Elimination of All Forms of Racial Discrimination (adopted and opened for signature and ratification by General Assembly resolution 2106 (XX) of 21 December 1965, entered into force 4 January 1969) 660 UNTS 195.

International Covenant on Civil and Political Rights (entered into force 23 March 1976) G.A. res. 2200A (XXI), 21 U.N. GAOR Supp. (No. 16) at 52, U.N. Doc. A/6316 (1966) 999 UNTS 171.

Justice Center for Legal Aid, <http://www.jcla-org.com/en/legal-aid-jordan>.

Latham \& Watkins LLP (2010), Pro Bono Practices and Opportunities in Jordan.

League of Arab States, Arab Charter on Human Rights, (adopted on 15 September 1994, published on the Jordanian Official Gazette (No 4675), dated 16 September 2004, page 4478).

Malcolm Evans, International Law (4th edn, Oxford University Press 2014).

Malcolm N. Shaw, International Law (6th edn, Cambridge University Press 2008).

Mayland McKimm, 'The Future of Legal Aid', (2010) 68 Advocate (Vancouver) 699.

Mohamed Olwan, 'Trafficking in Persons in Jordan' (2011) CRIMES AS 2011/42, Robert Schuman Centre for Advanced Studies, San Domenico di Fiesole (FI): European University Institute 1.

Mohammed Al-Moosa, 'The Application of International Conventions for Human Rights in the Jordanian Judiciary: The reality and Ways Available' Tamkeen for Legal Aid and Human Rights (Arabic edn).

Muddather Abu-Karaki, Raed Faqir and Majed Marashdah, 'Democracy \& Judicial Controlling in Jordan: A Constitutional Study' (2011) 4(2) Journal of Politics and Law 180.

Raman Mittal and K.V. Sreemithum (eds), Legal Aid: Catalyst for Social Change (Raman Mittal 2012).

Rome Statute of the International Criminal Court, (adopted by the United Nations Diplomatic Conference of Plenipotentiaries on the Establishment of an International Criminal Court on 17 July 1998, entered into force 1 July 2002) ISBN No. 92-9227-227-6.

Steven Eppler-Epstein, 'Passion, Caution, and Evolution: The Legal Aid Movement and Empirical Studies of 
Legal Assistance' (2012-2013) 126 Harv L Rev F 102.

The Jordanian Bar Association Law, as amended (No 11 of 1972) page 666 of the Official Gazette (No 2357) dated 6 April 1972.

The Jordanian Code of Criminal Procedures, as amended (No 9 of 1961) page 311 of the Official Gazette (No 1539) dated 16 March 1961.

The Jordanian Constitution (1952) page 3 of the Official Gazette (No 1093) dated 8 January 1952.

The Jordanian Juvenile Law (No 32 of 2014) page 6371 of the Official Gazette (No 5310) dated 2 November 2014.

The Jordanian Law of Societies (No 51 of 2008) page 4219 of the Official Gazette (No 4928) dated 16 September 2008.

The Jordanian Official Gazette (No 4539) dated 16 April 2002.

The Jordanian Official Gazette (No 4675) dated 16 September 2004.

The Jordanian Official Gazette (No 4764) dated 15 June 2006.

The Jordanian Official Gazette (No 4787) dated 16 October 2006.

The Jordanian Regulation of Legal Aid (No 119 of 2018) page 6675 of the Official Gazette (No 5541) dated 1 November 2018.

The Ministry of Justice, Directorate of Legal Assistance $<$ http://www.moj.gov.jo/Pages/viewpage.aspx?pageID=1330 $>$.

The Spanish Agency for International Development Cooperation (AECID), 'Access to Justice and Legal Empowerment in Jordan: Towards an Effective and Sustainable Legal Aid System' (2018).

United Nations Office on Drugs and Crime (UNODC), 'United Nations Principles and Guidelines on Access to Legal Aid in Criminal Justice Systems' (2013).

United Nations Office on Drugs and Crime (UNODC), Model Law on Legal Aid in Criminal Justice Systems with Commentaries (2017).

United Nations, Basic Principles on the Role of Lawyers, adopted by the Eighth United Nations Congress on the Prevention of Crime and the Treatment of Offenders, Havana, Cuba, 27 August to 7 September 1990.

Universal Declaration of Human Rights (adopted by the United Nations General Assembly on 10 December 1948), G.A. res. 217A (III), U.N. Doc A/810 at 71 (1948).

Vienna Convention on the Law of Treaties (adopted 23 May 1969, entered into force 27 January 1980) 1155 UNTS 331.

WANA Institute, 'The Status of Legal Empowerment in Jordan: Evidence to support the post-2015 development agenda' (2015). 